\title{
活性炭の表面状態が硝酸イオンの吸着に及ぼす影響
}

\author{
飯田 達也 ${ }^{1)}$ ，天野 佳正 $^{1,2)}$ ，相川 正美 ${ }^{3)}$ ，町田 基 ${ }^{1,2)}$ \\ 1) 千葉大学大学院工学研究科（ \\ 2) 千葉大学総合安全衛生管理機構（广263-8522 千葉県千葉市稲毛区弥生町1-33） \\ ${ }^{3)}$ 木更津工業高等専門学校（ ～292-0041 千葉県木更津市清見台東2-11-1）
}

[平成24年11月 14 日受付，平成25年 2 月 26 日受理］

\section{The Effect of the Surface Property of Activated Carbon on Nitrate Adsorption}

\author{
Tatsuya IIDA ${ }^{1)}$, Yoshimasa AMANO ${ }^{1,2)}$, Masami AIKAWA ${ }^{3)}$ and Motoi MACHIDA ${ }^{1,2)}$ \\ ${ }^{1)}$ Graduate School of Engineering, Chiba University \\ (1-33 Yayoi, Inage, Chiba, Chiba 263-8522) \\ ${ }^{2)}$ Safety and Health Organization, Chiba University \\ (1-33 Yayoi, Inage, Chiba, Chiba 263-8522) \\ ${ }^{3)}$ Faculty of Science, Kisarazu National College of Technology \\ (2-11-1 Kiyomidai, Kisarazu, Chiba 292-0041)
}

[Received November 14, 2012; Accepted February 26, 2013]

\begin{abstract}
Summary
In this study, the surface property of activated carbons (ACs) was modified by outgassing and ammonia gas treatment to remove the surface acidic functional groups and to introduce the basic sites into the carbon surface, respectively. Then, the nitrate ion adsorption was performed using the prepared ACs to examine the effect of surface charge of the ACs under various solution $\mathrm{pH}$. The competitive adsorption experiment between nitrate ion and nitrogen-containing aromatic compound was also conducted to specify the effective functional groups for the adsorption of nitrate ion. The result showed that low equilibrium $\mathrm{pH}\left(\mathrm{pH}_{\mathrm{e}}\right)$ of the solution enhanced the adsorption of nitrate ion, and the adsorption amount of nitrate ion at the same solution $\mathrm{pH}_{\mathrm{e}}$ was promoted according to the increase in the amount of basic sites on the ACs. When the $\mathrm{pH}_{\mathrm{e}}$ of the solution was lower than $\mathrm{pK}_{\mathrm{a}}$ of the aromatic compounds, the amount of nitrate ion adsorption was increased in the presence of aromatic compounds, and the significant adsorption was observed accompanying the increase in $\mathrm{pK}_{\mathrm{a}}$ value. Accordingly, it could be concluded that the basic groups possessing high $\mathrm{pK}_{\mathrm{a}}$ value could promote the adsorption of nitrate ion.
\end{abstract}

Key words: activated carbon, nitrate ion, adsorption, aromatic compound, surface property

\section{1.はじめに}

近年，化学肥料の過剩施肥や畜産業における未処理排泄物の流出 に伴う硝酸性窒素の地下水污染が問題となっている。硝酸性窒素を 多量に含む水を摂取すると，主に乳児を中心にメトへモグロビン血 症を引き起こしたり，体内で発癌性物質であるニトロソアミンを生 成したりする例が報告されている ${ }^{1-3)}$ 。環境省が実施した地下水の 継続監視調査によると, 硝酸性窒素掞よび亜硝酸性窒素の環境基準 超過井戸本数はテトラクロロエチレンやヒ素などの他の規制物質に 比べ最も多く年々増加傾向にある ${ }^{4)}$ 。このような実態に対応するた め, 日常生活で使用する水，特に飲料水から硝酸性窒素の簡便かつ 敏速な除去方法の確立が求められる。

水中の硝酸性窒素の除去方法としては, 逆浸透膜法5), 陰イオ ン交換法 ${ }^{6)}$, 生物的脱窒法7) などが挙げられるが, これらの方法は
コストや維持管理の面で課題が残る。一方，硝酸イオンをはじめ, さまざまな污染物質の除去に用いられている吸着法8) は, 操作が 簡便で特別な装置を必要としないという利点があり, 代表的な吸 着剂として活性炭がある。活性炭は微細孔を有する多孔質材料で $1000 \mathrm{~m}^{2} / \mathrm{g}$ 程度の非常に高い比表面積をもち, 表面が疎水性である ことから, 主に有機物質の吸着に用いられている9)。しかし, 最近 の研究では活性炭に化学的処理や熱的処理を施すことにより, イオ ン性物質の吸着にも有効な特性を付与できるという報告がなされて いる。例えば, 活性炭表面に酸性官能基を導入することにより, 重 金属イオンの吸着性能が増加する10,11), あるいはシリカやカーボン ナノチューブをアンモニア処理し, 窒素官能基を導入することによ り硝酸イオンの吸着量が増加する ${ }^{12,13)}$ 。また, イオン性物質の吸着 に有効な表面官能基を特定することを目的として, 重金属イオンと 特定の官能基を持つ芳香族化合物を同時吸着させた実験も報告され 
ている ${ }^{14,15)}$ 。ここでは, 活性炭に吸着しやすい芳香族化合物は活性 炭へ, 活性炭に吸着しにくい重金属は活性炭に吸着した芳香族化合 物の官能基へ吸着することが示されている。

本研究では, 表面酸性官能基を取り除くために脱気処理を施した 活性炭と，表面に窒素を導入するためにアンモニアガス処理を施し た活性炭を用い，溶液の $\mathrm{pH}$ を調整することにより表面電荷を変化 させ, 硝酸イオン吸着に及ぼす影響を調べた。さらに, 吸着に有効 な官能基を特定することを目的として, 共存する単環芳香族アミン 類が硝酸イオンの吸着に及ぼす影響を検討した。

\section{2. 実験方法}

\section{1 吸着剤の調製}

市販の粒状活性炭（カルゴンカーボンジャパン製，F400）を供 試炭として使用した。活性炭に残留している粉塵を取り除くため, 蒸留水を用いて煮沸洗浄を繰り返し 4 回行った後, $110{ }^{\circ} \mathrm{C} て ゙ 一$ 晚乾 燥した。活性炭に含まれる灰分を除去するために, $2 \mathrm{M} \mathrm{HCl}$ に $4 \mathrm{~h}$ 浸した後, $\mathrm{HCl}$ を取り替え一晚静置した。続いて, 46 \% HF に $5 \mathrm{~h}$ 浸した後，HF を取り替え一晚静置した。その後 $\mathrm{pH}$ が一定になる まで煮沸洗浄を繰り返し行い, $110{ }^{\circ} \mathrm{C}$ で一晚乾燥した。得られた F400をDA（deashing）とした。

\section{2 塩基性サイトの導入}

\section{2. 1 脱気処理}

$\mathrm{C} \pi$ 電子吸引性のある酸性官能基を除去するとともに酸性酸素官 能基を塩基性官能基に転化させるために，DA を石英管に入れ，環 状炉を用いて $\mathrm{He}$ 気流 $(150 \mathrm{~mL} / \mathrm{min})$ 中に抢いて昇温速度 $15{ }^{\circ} \mathrm{C} /$ $\min$ で $1000{ }^{\circ} \mathrm{C}$ まで昇温し $1 \mathrm{~h}$ 保持した。その後, (He 気流中で) 室温まで放冷した。得られた活性炭を 10 OG（outgassing）とした。

\section{2. 2 アンモニアガス処理}

DA を石英管に入れ，環状炉を用いて $\mathrm{He}$ 気流 $(150 \mathrm{~mL} / \mathrm{min})$ 中 において昇温速度 $15{ }^{\circ} \mathrm{C} / \mathrm{min} て ゙ 700{ }^{\circ} \mathrm{C}$ まで昇温した後, $\mathrm{NH}_{3}$ 気 流 $(250 \mathrm{~mL} / \mathrm{min})$ 中で $1 \mathrm{~h}$ 保持した。さらに, 物理吸着した $\mathrm{NH}_{3}$

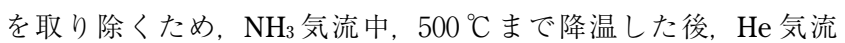
$150 \mathrm{~mL} / \mathrm{min}$ に切り替え, $0.5 \mathrm{~h}$ 保持した。その後, 室温まで放冷 した。これを $7 \mathrm{AG}$ (ammonia gas treatment）とした。

\section{3 活性炭の物性}

\section{3. 1 活性炭の表面積および元素組成}

活性炭の表面積は，比表面積測定装置（Beckman Coulter 製, SA3100）を使用して測定した。また，活性炭の元素組成は元素分 析装置（PerkinElmer製，PE2400）を用いて測定した。

\section{3. 2 表面官能基量の測定}

活性炭の表面酸性官能基量および表面塩基性サイト量は Boehm の方法 ${ }^{16)}$ に準拠して求めた。活性炭 $0.2 \mathrm{~g}$ を $25 \mathrm{~mL}$ の $0.1 \mathrm{M}$ $\mathrm{NaOH}, \mathrm{NaHCO}_{3}, \mathrm{HCl}$ および $0.05 \mathrm{M} \mathrm{Na}_{2} \mathrm{CO}_{3}$ に浸し $4 \mathrm{~d}$ 振とうさ せた。塩基性サイトは $\mathrm{HCl}$ との反応量から算出した。 $\mathrm{NaOH}$ はカ ルボキシル基, ラクトン基拉よびフェノール性ヒドロキシル基と, $\mathrm{Na}_{2} \mathrm{CO}_{3}$ はカルボキシル基拉よびラクトン基と, $\mathrm{NaHCO}_{3}$ はカルボ キシル基のみと中和反応する。各々の反応量を滴定から求め, 各酸 性㧍よび塩基性官能基量を算出した。

\section{3.3 表面ゼロ電荷点の測定}

活性炭の表面電荷がゼロを示す $\mathrm{pH}\left(\mathrm{pH}_{\mathrm{pzc}}\right)$ を測定するため, 蒸 留水 $50 \mathrm{~mL}$ の初期 $\mathrm{pH}$ を $\mathrm{HCl}$ (aq.) あるいは $\mathrm{NaOH}$ (aq.) を用い て調整した。初期 $\mathrm{pH}$ の異なる各水溶液に活性炭 $0.1 \mathrm{~g}$ を加え $4 \mathrm{~d}$ 振とうさせた後, 水溶液の平衡 $\mathrm{pH}\left(\mathrm{pH}_{\mathrm{e}}\right)$ を測定した。初期 $\mathrm{pH}$ と
平衡 $\mathrm{pH}$ をプロットし，2つの值が一致した $\mathrm{pH}$ を $\mathrm{pH}_{\mathrm{pzc}}$ とした。

\section{4 吸着実験}

\section{4. 1 吸着の $\mathrm{pH}$ 依存性}

初期の硝酸イオン濃度を $50 \mathrm{mg} / \mathrm{L}$ に調整した硝酸ナトリウム水

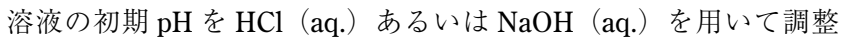
した。この水溶液 $50 \mathrm{~mL}$ と吸着剤 $0.1 \mathrm{~g}$ を $100 \mathrm{~mL}$ 三角フラスコに 加え, $25^{\circ} \mathrm{C}, 100 \mathrm{rpm}$ の条件で十分吸着平衡に達する $24 \mathrm{~h}$ 振とう した。上澄み液の硝酸イオン濃度を UV 分光光度計(島津製作所製, UV 2550）で測定し吸着量を算出した。

\section{4.2 芳香族化合物との共存吸着}

硝酸イオンの吸着量は, 芳香族化合物の平衡吸着量によって変化 すると考えられるため, 吸着実験で用いる芳香族化合物の初期濃 度を 50 〜 $2000 \mathrm{mg} / \mathrm{L}$ に調整した。芳香族化合物には $\mathrm{pK}_{\mathrm{a}} 4.8$ のア ニリンを比較対照として, $\mathrm{pK}_{\mathrm{a}}$ が 9.3 以上のベンジルアミンおよび フェネチルアミンを用いた。この 2 つ芳香族化合物は中性から酸 性域でプロトン化して, 硝酸イオンとの静電相互作用が増大するこ とが期待できる。硝酸イオンの初濃度は硝酸ナトリウム水溶液を用 いて $100 \mathrm{mg} / \mathrm{L}$ に調整した。溶液の初期 $\mathrm{pH}$ は $\mathrm{HCl}$ を用いて調整し た。塩化物イオンは硝酸イオンの吸着を阻害すると考えられるた め, 塩化ナトリウム水溶液を加えて初期塩化物イオン濃度 $\left(\left[\mathrm{Cl}^{-}\right]_{0}\right)$ を一定 $(30 \mathrm{mmol} / \mathrm{L})$ とした。溶液 $50 \mathrm{~mL}$ と基準活性炭とした DA $0.1 \mathrm{~g}$ を $100 \mathrm{~mL}$ 三角フラスコに入れ, $25^{\circ} \mathrm{C}, 100 \mathrm{rpm}$ の条件で十 分吸着平衡に達する $24 \mathrm{~h}$ 振とうした。その後, 上澄み液の硝酸 イオンと芳香族化合物濃度を UV 分光光度計（島津製作所製, UV 2550）で測定し, 硝酸イオンと芳香族化合物それぞれの吸着量を算 出した。

\section{3. 結果および考察}

\section{1 活性炭の性状}

調製した各活性炭の物性を Table 1 に示す。DAを脱気処理打よ びアンモニアガス処理したことにより，比表面積が８％ほど減少し た。10 OG および $7 \mathrm{AG} の \mathrm{pH}_{\mathrm{pzc}}$ は DA と比較して大きくなっており， 塩基性サイト量も増加している。10 OG の場合, 酸素含有率および 酸性官能基量の減少に伴う $\mathrm{C} \pi$ 電子密度の増加や酸性酸素官能基の 一部が塩基性官能基に転化したことが, 塩基性サイトの増加に寄与 した可能性がある。さらに, $7 \mathrm{AG}$ では窒素含有率が 4 倍以上増加 していることから, アンモニアガス処理によって塩基性窒素官能基 が導入されたと考えられる。

\section{2 溶液 $\mathrm{pH}$ の影響}

溶液の平衡 $\mathrm{pH}\left(\mathrm{pH}_{\mathrm{e}}\right)$ と硝酸イオン吸着量（ $\mathrm{Q}_{\mathrm{e}}$, nitrate $)$ の関係を Fig. 1 に示す。 $\mathrm{pH}_{\mathrm{e}}$ が小さくなるにつれて硝酸イオン吸着量が増加 する傾向が見られた。これは溶液中のプロトン量の増加に伴い, 活 性炭表面のプロトン量も多くなり, 正電荷密度が増大したためと 解釈できる。また, 同一の $\mathrm{pH}_{\mathrm{e}}$ では, 硝酸イオン吸着量が $7 \mathrm{AG}>$ $10 \mathrm{OG}>\mathrm{DA}$ の順で大きくなった。これはTable 1 に示した活性炭 の塩基性サイト量, 窒素含有率あるいは $\mathrm{pH}_{\mathrm{pzc}}$ に比例している。こ のため硝酸イオンの吸着は, 活性炭の塩基性サイトにプロトンが吸 着することにより表面が正に带電し, 負の電荷をもつ硝酸イオンと 静電相互作用することに起因していると考えられる。岡山ら ${ }^{17)}$ は, $700{ }^{\circ} \mathrm{C}$ でのンモニアガス処理により, 活性炭表面にアミン窒素, ピロール窒素拉よびピリジン窒素を導入できることを示している。 導入された窒素の非共有電子対がルイス塩基として働き，プロトン を受容できるため, $7 \mathrm{AG}$ の硝酸イオンの吸着量増加に寄与したと 
考えられる。

\section{3 硝酸イオンと芳香族化合物の共存吸着}

$\mathrm{pH}_{\mathrm{e}} 2$ に扮ける $\mathrm{Q}_{\mathrm{e}, \text { nitrate }}$ と芳香族化合物の平衡吸着量 ( $\mathrm{Q}_{\mathrm{e}, \text { aromatic }}$ ) の関係を Fig. 2 に示す。Qe, nitrateについては, $\mathrm{pH}_{\mathrm{e}} 3$ では 0.22 $\mathrm{mmol} / \mathrm{g}$ (Fig. 1) であったのに対し, $\mathrm{pH}_{\mathrm{e}} 2$ では $0.15 \mathrm{mmol} / \mathrm{g}$ (Fig. 2, $\mathrm{Q}_{\mathrm{e}, \text { aromatic }}=0$ のときの $\left.\mathrm{Q}_{\mathrm{e}, \text { nitrate }}\right)$ であった。陰イオンが共存すると 硝酸イオン吸着を妨害することが報告されており 整する際, 添加した多量の $\mathrm{HCl}$ に由来する塩化物イオンが硝酸イ オン吸着を妨害したためと考えられる。 $\mathrm{pH}_{\mathrm{e}} 2$ では芳香族化合物が 存在するとき，アニリン，ベンジルアミンおよびフェネチルアミン の吸着量の増加に伴い, 硝酸イオンの吸着量が増加した。硝酸イオ ンとフェネチルアミンの共存吸着においては，フェネチルアミンの 吸着量が $1.2 \mathrm{mmol} / \mathrm{g}$ のとき, 硝酸イオンの吸着量が $0.31 \mathrm{mmol} /$ $\mathrm{g}$ とフェネチルアミンが存在しないときと比べて, 約 2 倍の高い吸 着量を示した。しかし, 溶液の $\mathrm{pH}_{\mathrm{e}}$ が各芳香族化合物の $\mathrm{pK}_{\mathrm{a}}$ 值付 近もしくはそれ以上になったときは，陰イオンである硝酸イオンは ほとんど吸着しなかった。これは芳香族化合物の官能基がプロトン 化しなかったことに起因すると考えられる。アニリン，ベンジルア ミンおよびフェネチルアミンの $\mathrm{pK}_{\mathrm{a}}$ 值はそれぞれ 4.87，9.34 およ び 9.83 であり ${ }^{18)}, \mathrm{pH}_{\mathrm{e}} 2$ では活性炭表面に吸着したすべての芳香族 化合物のもつアミノ基がプロトン化し正に帯電する。これが硝酸イ オンと静電相互作用し，吸着サイトとしての役割を果たしていると 考えられる。中でも， $\mathrm{pK}_{\mathrm{a}}$ 值の高い，芳香環にメチレン基 $\left(-\mathrm{CH}_{2}-\right)$
を介して結合しているアミノ基が吸着に大きく寄与していることが 推察される。但し, ベンジルアミンにおいては吸着量が $1 \mathrm{mmol} / \mathrm{g}$ 以上になると, 硝酸イオンの吸着量が減少する傾向が見られた。こ のことは芳香族化合物がもともと活性炭上に存在する硝酸イオンの 吸着サイトをも占有して吸着阻害を引き起こしたためと思われる。

以上の結果から，芳香環にメチレン基を介して結合しているアミ ノ基を有する, $\mathrm{pK}_{\mathrm{a}}$ 值の高い塩基性官能基の導入が硝酸イオン吸着 に有効であると考えられる。7 AG は DA および 10 OG と比べて中 性域でも優位であることから， $7 \mathrm{AG}$ 表面上の窒素にも一部 $\mathrm{pK}_{\mathrm{a}}$ 值 の高い塩基性サイトが存在していることが示唆される。今後, この ような硝酸イオンに有効なサイトを炭素表面に導入し, 地下水等の 実際の試料への適用を検討していく必要がある。

\section{4. 結論}

本研究では，表面酸性官能基を除去するために脱気処理を施した 活性炭と, 表面に窒素を導入するためにアンモニアガス処理を施し た活性炭を用い, 溶液 $\mathrm{pH}$ を変化させて表面電荷が硝酸イオンの吸 着に及ぼす影響を検討した。また，硝酸イオンと含窒素芳香族化合 物の共存吸着を行い, 芳香族化合物の官能基が硝酸イオンの吸着に 及ぼす影響についても検討した。得られた結果は以下の通りである。 ・溶液の $\mathrm{pH}$ が酸性側になるにつれて, また脱気やアンモニア処理 により活性炭表面の塩基性サイト量を増加させることで硝酸イオ ンの吸着量が増加した。

Table 1 Structure and surface properties of activated carbons (ACs)

\begin{tabular}{|c|c|c|c|c|c|c|c|c|c|c|}
\hline \multirow[b]{2}{*}{$\mathrm{AC}$} & \multirow{2}{*}{$\begin{array}{c}\mathrm{S}_{\mathrm{BET}} \\
\left(\mathrm{m}^{2} / \mathrm{g}\right)\end{array}$} & \multicolumn{4}{|c|}{ Elemental composition $(\mathrm{wt} \%)$} & \multicolumn{3}{|c|}{ Acidic sites (meq./g) } & \multirow{2}{*}{$\begin{array}{c}\text { Basic } \\
\text { site } \\
\text { (meq./g) }\end{array}$} & \multirow[b]{2}{*}{$\mathrm{pH}_{\mathrm{pzc}}$} \\
\hline & & $\mathrm{C}$ & $\mathrm{H}$ & $\mathrm{N}$ & $\mathrm{O}$ & $\begin{array}{c}\text { carboxylic } \\
(-\mathrm{COOH})\end{array}$ & $\begin{array}{l}\text { lactonic } \\
(-\mathrm{COO}-)\end{array}$ & $\begin{array}{l}\text { phenolic } \\
(\mathrm{Ar}-\mathrm{OH})\end{array}$ & & \\
\hline DA & 1106 & 93.40 & 0.03 & 0.39 & 6.17 & 0.04 & 0.02 & 0.48 & 0.12 & 6.8 \\
\hline $100 G$ & 1013 & 96.40 & 0.13 & 0.43 & 3.00 & 0.00 & 0.00 & 0.38 & 0.51 & 9.3 \\
\hline $7 \mathrm{AG}$ & 1018 & 95.10 & 0.20 & 1.86 & 2.85 & 0.00 & 0.00 & 0.04 & 0.67 & 9.8 \\
\hline
\end{tabular}

DA: deashed $\mathrm{AC}(\mathrm{F} 400), 10 \mathrm{OG}$ : outgassed $\mathrm{AC}(\mathrm{DA})$ at $1000^{\circ} \mathrm{C}$,

7AG: ammonia gas treated $\mathrm{AC}(\mathrm{DA})$ at $700^{\circ} \mathrm{C}$

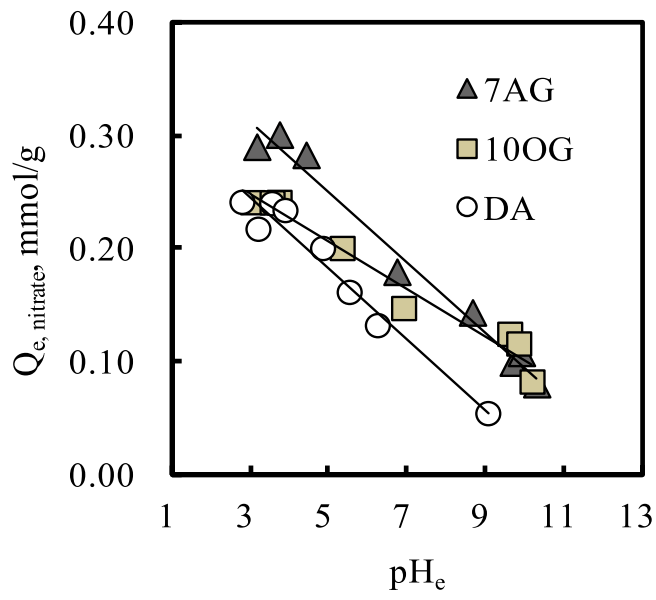

Fig. 1 The effect of equilibrium solution $\mathrm{pH}$ on the amount of nitrate adsorption, DA: deashed AC (F400), 10 OG: outgassed $\mathrm{AC}(\mathrm{DA})$ at $1000{ }^{\circ} \mathrm{C}, 7 \mathrm{AG}$ : ammonia gas treated AC (DA) at $700{ }^{\circ} \mathrm{C}$

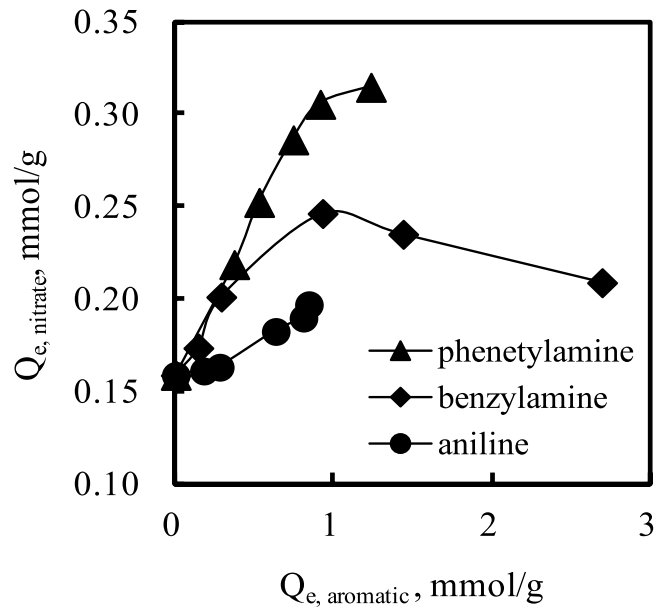

Fig. 2 Relationship of the adsorption amounts between nitrate and aromatic compounds, (Adsorbent: $\mathrm{DA}, \mathrm{pH}_{\mathrm{e}} 2,\left[\mathrm{Cl}^{-}\right]_{0}$ $=30 \mathrm{mM})$, DA: deashed AC (F400), $\left[\mathrm{Cl}^{-}\right]_{0}$ : initial concentration of chloride 
・硝酸イオンとアミノ基を有する芳香族化合物の共存条件下では, 芳香族化合物の $\mathrm{pK}_{\mathrm{a}}$ より低い $\mathrm{pH}_{\mathrm{e}}$ のときに硝酸イオンの吸着量 は硝酸イオン単独のときより増加し，その増加量は $\mathrm{pK}_{\mathrm{a}}$ が高いほ ど顕著であった。

・アンモニア処理活性炭上にも一部 $\mathrm{pK}_{\mathrm{a}}$ の高い塩基性官能基が存在 することが示唆された。

\section{要 約}

本研究では, 脱気処理およびアンモニアガス処理により塩基性开 イトを導入した活性炭（AC）を用い，溶液 $\mathrm{pH}$ を変化させること により表面電荷を変化させ，硝酸イオンの吸着に及ぼす影響を検討 した。また，含窒素芳香族化合物と硝酸イオンの共存吸着を行い， 芳香族化合物の官能基が硝酸イオン吸着量に及ぼす影響も検討し た。その結果, $\mathrm{pH}_{\mathrm{e}}$ が小さいほど硝酸イオン吸着量が増加すること がわかり,さらに, 同一の $\mathrm{pH}_{\mathrm{e}}$ では塩基性サイト量が多いほど硝 酸イオン吸着量が増加することが示唆された。また, 塩基性官能基 を有する芳香族化合物が共存し，その芳香族化合物の $\mathrm{pK}_{\mathrm{a}}$ より小さ い $\mathrm{pH}_{\mathrm{e}}$ では, 硝酸イオン単独のときより硝酸イオン吸着量が増加し, その増加量は $\mathrm{pK}_{\mathrm{a}}$ が高いほど顕著であった。これより, $\mathrm{pK}_{\mathrm{a}}$ の高い 塩基性官能基が硝酸イオン吸着に効果的であることが示唆された。

\section{謝 辞}

本研究の一部は, 日本学術振興会 ·科学技術研究費補助金 · 基盤 研究 C「水質污染物質の吸着 - 分解除去のための高性能活性炭の設 計（No. 23510091）」の助成を受けたものです。また，本研究を進 めるにあたり, 多岐にわたるご支援をいただきました千葉大学総合 安全衛生管理機構の今関文夫機構長 (教授, 医学博士) に厚く御礼 申し上げます。

\section{文 献}

1）農業と地下水の硝酸污染. pp20-38, 「地下水の硝酸污染と農 法転換」. 小川吉雄, 農山漁村文化協会, 東京 (2000)

2) Knobeloch, L., Salna, B., Hogan, A., Postle, J. and Anderson, H.: Blue babies and nitrate-contaminated well water. Environmental Health Perspectives. 108, 675-678 (2000)

3) Cantor, K.P.: Drinking water and cancer. Cancer Causes and Control. 8, 292-308 (1997)

4）環境省：平成22年度地下水質測定結果

5) Schoeman, J.J.: Nitrate-nitrogen removal with small-scale reverse osmosis, electrodialysis and ion-exchange units in rural areas. Water S. A. 35, 721-728 (2009)
6) Kim, J. and Benjamin, M.M.: Modeling a novel ion exchange process for arsenic and nitrate removal. Water Research. 38, 20532062 (2004)

7) Mateju, V., Cizinska, S., Krejci, J. and Janoch, T.: Biological water denitrification-A review. Enzyme and Microbial Technology. 14, 170-183 (1992)

8) Öztürk, N. and Bektaş, T.E.: Nitrate removal from aqueous solution by adsorption onto various materials. Journal of Hazardous Materials. 112, 155-162 (2004)

9) Singh, K.P., Mohan, D., Sinha, S., Tondon, G.S. and Gosh, D.: Color removal from wastewater using low-cost activated carbon derived from agricultural waste material. Industrial and Engineering Chemistry Research. 42, 1965-1976 (2003)

10）吉原和矢, 相川正美, 町田 基: 活性炭による重金属イオン 吸着に及ぼす $\mathrm{pH}$ および共存電解質の影響. 炭素. 237, 61-66 (2009)

11) Chen, J.P. and Wu, S.: Acid/base-treated activated carbons: Characterization of functional groups and metal adsorptive properties. Langmuir. 20, 2233-2242 (2004)

12) Saad, R., Hamoudi, S. and Belkacemi, K.: Adsorption of phosphate and nitrate anions on ammonium-functionnalized mesoporous silica. Journal of Porous Materials. 15, 315-323 (2008)

13) Tofighy, M.A. and Mohammadi, T.: Nitrate removal from water using functionalized carbon nanotube sheets. Chemical Engineering Research and Design. 90, 1815-1822 (2012)

14）古宿麻美, 天野佳正, 町田 基：Cd（II）の活性炭素緘維へ の吸着に及ぼす芳香族化合物の共存効果. 繊維学会誌. 68 , 138-141 (2012)

15) Faur-Brasquet, C., Kadirvelu, K. and Le Cloirec, P.: Removal of metal ions from aqueous solution by adsorption onto activated carbon cloths: Adsorption competition with organic matter. Carbon. 40, 2387-2392 (2002)

16) Boehm, H.P.: Surface oxides on carbon and their analysis: a critical assessment. Carbon. 40, 145-149 (2002)

17）岡山玲子, 天野佳正, 町田 基: 活性炭表面上の窒素が銅（II） イオンの吸着に及ぼす影響。炭素．242，45-50（2010）

18) Lide, D.R.: Analytical chemistry. pp $46-56$, “CRC handbook of chemistry and physics, 82nd edition" Edited by Lide, D.R., CRC Press, USA (2001)

19) Przepiórski, J., Skrodzewicz, M. and Morawski, A.W.: High temperature ammonia treatment of activated carbon for enhancement of $\mathrm{CO}_{2}$ adsorption. Applied Surface Science. 225, 235-242 (2004) 